\title{
Mobility, Indexicality, and the Enregisterment of "Pittsburghese"
}

(C) 2006 Sage Publications $10.1177 / 0075424206290692$ http://eng.sagepub.com hosted at http://online.sagepub.com

\section{Barbara Johnstone \\ Jennifer Andrus \\ Carnegie Mellon University, Pittsburgh, Pennsylvania}

Andrew E. Danielson

University of California, Berkeley

This article explores the sociolinguistic history of a U.S. city. On the basis of historical research, ethnography, discourse analysis, and sociolinguistic interviews, the authors describe how a set of linguistic features that were once not noticed at all, then used and heard primarily as markers of socioeconomic class, have come to be linked increasingly to place and "enregistered" as a dialect called "Pittsburghese." To explain how this has come about, the authors draw on the semiotic concept of "orders of indexicality." They suggest that social and geographical mobility during the latter half of the twentieth century has played a crucial role in the process. They model a particularistic approach to linguistic and ideological change that is sensitive not only to ideas about language that circulate in the media but also to the life experiences of particular speakers; and they show how an understanding of linguistic variation, language attitudes, and the stylized performance of dialect is enhanced by exploring the historical and ideological processes that make resources for these practices available.

Keywords: American English; dialect; discourse analysis; enregisterment; history; indexicality; individuals; interviews; media; metadiscourse; metapragmatics; mobility; Pennsylvania; Pittsburgh; Pittsburghese

\footnotetext{
Authors' Note: Work on this project was partially supported by U.S. National Science Foundation Award Number BCS-0417657. Johnstone and Andrus presented an earlier version of part of this paper at the University of Cardiff conference on Language and Global Communication in July 2005; they are responsible for the overall structure of the argument and the analysis of the interview data, which they collected. We also draw on earlier work by Danielson on the Carnegie Library of Pittsburgh newspaper archive (Johnstone and Danielson 2001), although Danielson was not involved in the preparation of this article and bears no responsibility for any of its failings. For help with Silverstein, Johnstone is grateful to fellow members of the Carnegie Mellon University/University of Pittsburgh Social Meaning in Language group during the fall semester of 2005: Scott F. Kiesling, Brian Brubaker, Maeve Eberhart, and Veronica Lifrieri. We are grateful to Dan Baumgardt and Scott F. Kiesling for doing the coding and analysis of /aw/-monophthongization that resulted in the index scores for this variable. Comments from two anonymous reviewers and this journal's editors, Anne Curzan and Robin Queen, have helped sharpen the argument.
} 
$\mathrm{T}$ his article explores the twentieth-century sociolinguistic history of a U.S. city. On the basis of historical research, ethnography, discourse analysis, and sociolinguistic interviews, we describe how a set of linguistic features that were once not noticed at all, then used and heard primarily as markers of socioeconomic class, have come to be linked increasingly to place and "enregistered" (Agha 2003) as a dialect called "Pittsburghese." Speech features now thought of as local figure in practices of social identification as potential markers of social class and local orientation and as tools for making more self-conscious regional identity claims (Schilling-Estes 1998; Coupland 2001; Johnstone 1999b). To explain this process, we draw on Michael Silverstein's (1976/1995, 2003) discussion of "orders of indexicality," tracing how "first-order" correlations between demographic identities and linguistic usages (Labov's 1972b, 178, "indicators") came to be available for "second-order" sociolinguistic "marking" (Labov 1972b, 179) of class and place, and then how certain of these indexical relations between linguistic forms and social meanings became resources for the "thirdorder" indexical use of sociolinguistic "stereotypes" (Labov 1972b, 180) in more reflexive identity work. We suggest that social and geographical mobility during the latter half of the twentieth century, driven by economic changes in the region connected with the globalizing economy, has played a crucial role in this process.

Our evidence comes from several sources. To trace the historical emergence of explicit metapragmatic discourse about the social meaning of local linguistic forms, we draw on an archive of newspaper articles about Pittsburgh speech published between 1910 and 2001. To see how these public representations arise from and play out in individuals' sociolinguistic life histories (Johnstone 1999a, 2000a), we also draw on data collected in the course of sociolinguistic interviews and related experimental tasks, on historians' research about the city and on more than eight years of participant observation in Pittsburgh. We explore how five Pittsburghers use and talk about local speech, particularly as it relates to class and region. Growing up at different times; in the context of different circulating public representations of speech, class, and place; and with different ways of experiencing local language in daily life, each of these people hears, feels about, and talks about local speech in a different set of ways. As a result, these case studies allow us to illustrate the multiple and changing semiotic relationships between local speech features and social identity in considerable detail and at a very fine-grained level of particularity.

In addition to arguing for the relevance of the ideas of enregisterment and indexicality to the historical dialectology of American English, we model a particularistic approach to linguistic and ideological change that is sensitive not only to ideas about language that circulate in the media but also to the life experiences of particular speakers. Furthermore, we show how an understanding of variability in speech communities, language attitudes, and the stylized performance of dialect is enhanced by exploring the historical and ideological processes that make resources for these practices available. 


\section{Why Globalization Collapses Regional Linguistic Distinctions and Creates Regional Dialects}

Geographic mobility associated with the globalizing economy has resulted at the same time in dialect leveling, or the collapse of distinctions among regional varieties (Trudgill 1986; Milroy 2002; Auer, Hinskens, and Kerswill 2005), and, at least in some places, in increased popular attention to regional variation (Beal 1999; Johnstone 2000b). ${ }^{1}$ This is because the social and economic conditions that cause people to speak more alike are the same as those that give rise to the activities in which "dialects" are constructed and standardized as shared representations of ways of speaking, semiotically linked to place and other aspects of social identity. Work by linguistic anthropologists Michael Silverstein and Asif Agha provides a framework for understanding this apparent paradox.

Associations between particular features of pronunciation, grammar, and vocabulary, on one hand, and imagined "languages," "dialects," and "speech communities," on the other, arise in local social and discursive practices that are enabled and constrained by larger-scale political and economic conditions. According to Michael Silverstein (1998, 408), "users of languages in essence construct culturally particular concepts of [linguistic] normativity that bind subsets of them into 'language'-bearing groups." That is to say that "languages" and "dialects" are cultural constructs, produced by a group of people using, or orienting to and/or talking about, a particular set of linguistic features, in a process that also constructs the group itself (Gal and Irvine 1995). The links between social groups and languages are thus unstable, especially with increasing geographic mobility facilitated by a globalizing economy that creates situations in which people come into contact with other ways of speaking. As a result of such contact, argued Silverstein, communities become more and more aware of and reflexive about their language and their related "groupness" (1998, 415). Linguistic forms that were previously unnoticed in the community, because everyone in a speaker's social network used them, become noticeable in contrast with new forms emanating from elsewhere, and variability can become semiotically linked with social categorization in new ways.

Like languages and speech communities, linguistic locality — what it means linguistically to be "here" or "from here" and how places and ways of speaking are thought to be related-is also a product of discourse, arising as "particular, geopolitically conceptualized, bounded swatches of the earth [are] attached to particular labels for 'languages' - and their bearers" (Silverstein 1998, 405; see also Johnstone 2004). Recent global-scale processes such as colonization, decolonization, global economies in which communication and information are commodified, and diasporic flows of people have created a situation in which locality has been destabilized (Silverstein 1998, 404).

In a study of the history of Received Pronunciation (RP) in Britain, Asif Agha (2003) pointed to some of the mechanisms involved in what, borrowing the term from Silverstein, he called "enregistration": the identification of a set of linguistic forms as 
a "linguistic repertoire differentiable within a language as a socially recognized register," which has come to index "speaker status linked to a specific scheme of cultural values" (p. 231). What became RP was once a regional variety, used by socially privileged speakers in a geographically bounded area in southeastern England and not associated with correctness more generally or advocated as a national model for pronunciation. Since the eighteenth century, however, as a result of a variety of prescriptivist ideas and metapragmatic activities that have circulated these ideas, a set of features of this regional variety have been enregistered as a supralocal standard accent; these features have been represented collectively in the public imagination as a stable variety and maintained across time and region via metapragmatic practices that reiterate the value of this variety and its link to social status and correctness.

Not all of these metapragmatic processes involve explicit talk about talk. People may notice, for example, that BBC radio announcers and other "exemplary" speakers use RP without having this explicitly called to attention, since the fact that the $\mathrm{BBC}$ is a prestigious national broadcaster itself suggests that RP should be heard as a prestigious national variety. In general, not all metapragmatic activities-activities that point to a feature's appropriate context of use-involve explicit metadiscourse, or talk about talk. This accounts for the well-known fact that people are not always consciously aware of links between linguistic forms and social meanings, even when they use the forms appropriately in their own speech. Once the links are somewhat stabilized, however, people can in some circumstances also reflexively respond to the social meanings of linguistic forms, explicitly talking about appropriate usage in handbooks, representing users of the forms in cartoons, and so on. Explicit metadiscourse may play a greater role in the standardization of a prestige variety like RP than in the standardization of a vernacular variety.

Our project in this article is to explore the semiotic processes Silverstein has sketched in a case that differs from Agha's in some interesting ways. While both we and Agha are interested in the historical emergence of shared ways of representing and using a named variety ("RP" in Agha's case, "Pittsburghese" in ours), discourse about "correctness" plays a smaller (though not negligible) role in our case than in Agha's, and while in Agha's case a variety once linked with a region has been de-localized and linked to social status instead, the trend in our case has been the opposite. Agha's case study involves the standardization of a prestige variety, while ours involves the standardization of a "nonstandard" regional variety. Our study thus speaks to the formation, not of the kind of prestige norms speakers would draw on to sound correct, but of "vernacular" norms (Wolfram 2003) speakers can draw on to sound workingclass or local. We suggest that the processes involved are the same in both cases.

\section{Indexicality and Enregisterment}

To organize our account of the changing connections in Pittsburgh between linguistic form and social meaning, we turn to Silverstein's (1976/1995, 1976, 2003) 
"orders of indexicality." Silverstein uses Charles Pierce's term "index" to label "signs where the occurrence of the sign vehicle token bears a connection of understood spatio-temporal contiguity to the occurrence of the entity signaled" (Silverstein 1976/1995, 199). Indexes can be referential, as in the case of "shifters" like demonstrative and personal pronouns such as here or you, where the denotation of the term depends on the context of its utterance. We are concerned here, however, with nonreferential indexes: linguistic forms that evoke and/or construct (Silverstein uses the terms presuppose and entail) what is sometimes called "social meaning," a concept that encompasses matters such as register (in the narrower sense of situational appropriateness), stance (certainty, authority, etc.), and social identity (class, ethnicity, interactional role, etc.).

Relationships between linguistic form and social meaning can stabilize at various levels of abstraction or "orders of indexicality." According to Silverstein (2003, 193), "any $n$-th order indexical presupposes that the context in which it is normatively used has a schematization of some particular sort, relative to which we can model the 'appropriateness' of its usage in that context." Silverstein claims that the concept of indexical order is necessary for "showing us how to relate the microsocial to the macro-social frames of analysis of any sociolinguistic phenomenon" (p. 193). In a 2003 article, Silverstein compared orders of indexicality with William Labov's (1972b, 178-80) taxonomy of the kinds of social meanings linguistic variables can carry (Silverstein 2003, 216-22). Table 1 elaborates this comparison. Labov's taxonomy is meant to label the kinds of stabilized linguistic form-social meaning connections that he has observed while tracing the history of particular sound changes. In the context of proposing a theory of language and culture, Silverstein (2004) has focused on the processes by which linguistic forms acquire social meanings, so his taxonomy is more abstract than Labov's. Like Labov, we are interested in the historical process by which "indicators" can become "markers" and then "stereotypes." We supplement the Labovian taxonomy with Silverstein's concept of indexical order because it allows for a more nuanced understanding of how this process works.

In Silverstein's terms, we are interested in a particular instantiation of the process by which an $n$-th-order correlation can give rise to $n+1$-th-order social meaning and $n+1$-th-order connections between linguistic forms and social meanings can themselves be invested with meaning, becoming the presupposing $n$-th-order pattern for a new $n+1$-th-order entailment. To identify orders of indexicality that can be historically observed, we thus assign actual values to Silverstein's variable $n$ in sketching the history of dialect enregisterment in Pittsburgh. "First-order" indexicality is the kind of correlation between a form and a sociodemographic identity or pragmatic function that an outsider could observe. In Labov's taxonomy, first-order indexicals are "indicators." For example, work by Labov, Ash, and Boberg (2005); Johnstone, Bhasin, and Wittkofski (2002); and Kiesling and Wisnosky (2003) shows that the monophthongization of the diphthong /aw/ (so that house sounds like [ha:s]) occurs in the speech of people from a particular part of southwestern Pennsylvania and 
Table 1

\section{Types of Indexical Meaning, according to Labov (1972b, 178-80) and Silverstein (2003), and Their Application in Pittsburgh}

Labov
"indicator": A variable
feature that shows no pattern
of stylistic variation in users'
speech, affecting all items in
the relevant word classes.
Speakers are not aware of the
variable. The variable is
"defined as a function of
group membership," or, as its
use spreads in subsequent
generations, group
membership and age.

"marker": A variable feature that shows stylistic variation, that is, speakers use different variants in different contexts, because the use of one variant or another is socially meaningful. Markers are "norms which define the speech community," to which members of the community react in "a uniform manner," although without necessarily being aware of the variables or their social meanings.
Silverstein

" $\boldsymbol{n}$-th-order indexical": A

feature whose use can be correlated with a

sociodemographic identity (e.g., region or class) or a semantic function (e.g., number-marking). $\mathrm{N}$-th-order accounts are "scientific" (p. 205), that is, could be generated by a cultural outsider such as a linguist. The feature's indexicality is "presupposing": occurrence of the feature can only be interpreted with reference to a preexisting partition of social or semantic space.

\section{“ $n+1$-th-order indexical": An}

$n$-th order indexical feature that has been assigned "an ethno-metapragmatically driven native interpretation" (p. 212), that is, a meaning in terms of one or more native ideologies (the idea that certain people speak more correctly than others, for example, or that some people are due greater respect than others). The feature has been "enregistered," that is, it has become associated with a style of speech and can be used to create a context for that style. Its indexicality is thus "entailing" or "creative."

"For any indexical phenomenon at order $n$, an indexical phenomenon at order $n+1$ is always immanent, lurking in the potential of an ethnometapragmatically driven native interpretation of the $n$-th-order paradigmatic contextual variation

\author{
In Pittsburgh
}

First-order indexicality: The frequency of regional variants can be correlated with being from southwestern Pennsylvania, especially from Pittsburgh, and with being working-class and male. But for socially nonmobile speakers in dense, multiplex social networks, these correlations are not noticeable, because "everybody speaks that way."

\section{Second-order indexicality:}

Regional features become available for social work; speakers start to notice and attribute meaning to regional variants and shift styles in their own speech. The meaning of these forms is shaped mainly by ideologies about class and correctness, though regional forms can also be linked with locality by people who have had the "localness" of these forms called to attention.

Third-order indexicality: People noticing the existence of secondorder stylistic variation in Pittsburghers' speech link the regional variants they are most likely to hear with Pittsburgh identity, drawing on the increasingly widely circulating 
Table 1 (continued)

\begin{tabular}{lll}
\hline Labov & Silverstein & In Pittsburgh \\
\hline that it creates or constitutes as a & $\begin{array}{l}\text { idea that places and dialects are } \\
\text { register phenomenon" (p. 212). } \\
\text { In the case of Labovian }\end{array}$ & $\begin{array}{l}\text { a dialect). These people, who } \\
\text { include Pittsburghers and non- }\end{array}$ \\
"stereotypes," " $n+1$ st order & $\begin{array}{l}\text { Pittsburghers, use regional forms } \\
\text { indexicality has become }\end{array}$ \\
presupposing . . replacing an from highly codified lists to \\
older n-th order indexical & perform local identity, often in \\
presupposition" (p. 220) & ironic, semiserious ways. \\
\hline
\end{tabular}

rarely elsewhere, and it is more likely to occur in the speech of working-class males born in Pittsburgh than in that of other people. Thus monophthongal /aw/ is an indicator (Labov) or first-order index (Silverstein) of someone's being from that area, working class, and/or male.

Because the form-social category connection only begins to be meaningful when someone notices it, first-order indexicality is potential indexicality. In the case of /aw/-monophthongization, the correlation between monophthongization and speakers' class and place of origin exists because linguists have noted it, and making the correlation requires a system for dividing people up into place-based or classbased categories that is already in place when we count tokens of monophthongal /aw/. Sociolinguistic descriptions of patterns of variation in the Pittsburgh area do not, in other words, use /aw/- monophthongization as a clue to where speakers are from or what their socioeconomic status is. In the early stages of a sound change, speech community members behave the same way, since the variable in question is not invested with social meaning. In Silverstein's terms, /aw/-monophthongization "presupposes" class and place, but it does not "entail" them until the connection has been made between the variant and social meaning for speakers of the variety. During the first stage of a sound change, when a variable is a Labovian indicator, community members have not noticed the first-order indexical correlation between form and demography, and they thus cannot make use of the correlation to interpret others' speech or project social identity.

Second-order indexicality occurs when people begin to use first-order correlations to do social work, either interpretive or performative. For example, because monophthongal /aw/ is distributed the way it is, someone who has noticed this distribution can hear monophthongal /aw/ as suggesting that the speaker is from southwestern Pennsylvania and/or working-class and/or (in case of ambiguity) male. Accordingly, people who can use this feature variably may use it less when they are trying harder to sound educated or cosmopolitan, or more when they are trying harder to sound like working-class men or like other Pittsburghers. Labov refers to linguistic forms that do this kind of work as "markers."2 
Orders of indexicality are in dialectical relationships with one another. Secondorder social meaning is shaped by first-order correlations, and the existence of second-order indexical relations influences the first-order "facts on the ground," since the sociolinguistic value of a form affects the demographic distribution of its use. Second-order indexicality involves " 1 st-order indexical variation that has been swept up into an ideologically-driven metapragmatics" (Silverstein 2003, 219). (As noted above, "metapragmatic" activity is not necessarily "metadiscursive," so speakers are not necessarily aware of second-order indexicality in such a way as to be able to talk about it.) In general, $n+1$-th-order indexicality occurs when $n$-th-order indexical relations are noticed, consciously or not, and given meaning, becoming pragmatically usable. As we will show, second-order indexical relations link phonetic and lexical form with "social meaning" in several ways: drawing meaning from several sets of ideas about language, nonstandard forms hearable in Pittsburgh can sound incorrect, working-class, local, or some combination of these.

In Pittsburgh, the (aw) variable acquires third-order indexical meaning when it gets "swept up" into explicit lists of local words and their meanings and reflexive performances of local identities, in the context of widely circulating discourse about the connection between local identity and local speech. Only a subset of the features of regional speech have been taken up into the third order of indexicality, in which using words and pronunciations from a highly codified repertoire is a way people who may have few of the resources for second-order indexicality can show that they know how Pittsburghers sound. In third-order indexicality, the meanings of these forms are increasingly linked to place, though they can still be used to evoke class in the context of local identity.

To explore how shifting indexicalities have shaped and been shaped by Pittsburghers' sociolinguistic experience over the course of the twentieth century, we draw on sociolinguistic interviews with 5 of the 101 Pittsburghers who have participated in four neighborhood studies that were part of a larger project on language change, place identity, and dialect awareness in the Pittsburgh area, directed by Barbara Johnstone and Scott F. Kiesling. During the interviews, we ask people to talk about local speech. The 5 speakers we discuss here, all of whom were interviewed by Johnstone or Johnstone and Andrus together, represent the range of ways Pittsburghers talk about local speech and its social meanings, and we have chosen them out of the larger sample for that reason. They live in two of the three predominantly white neighborhoods in which interviews were conducted: Lawrenceville, an inner-city working-class neighborhood that is now in the early stages of gentrification (so that housing is still inexpensive there); and Forest Hills, an older, "inner-ring" suburb that boomed in the post-World War II years. All of the 5 have been geographically mobile, within the Pittsburgh area and in some cases outside of it, and the 3 oldest have all been socially mobile, moving from workingclass childhoods to middle-class adulthoods, by their own reckoning. These facts could have enabled all of them to experience regional speech in multiple ways. Two are 
Table 2

Demographic and Linguistic Sketches of Case-Study Speakers

\begin{tabular}{|c|c|c|c|}
\hline Pseudonym & $\begin{array}{l}\text { Date of } \\
\text { Birth }\end{array}$ & Life History Sketch & $\begin{array}{c}\text { Index Score } \\
\text { for (aw) }\end{array}$ \\
\hline Dr. John K. & 1928 & $\begin{array}{l}\text { Retired; owned a medical laboratory. The son of a firefighter, } \\
\text { he grew up in a mostly working-class neighborhood, } \\
\text { eventually settling in Forest Hills, a white-collar suburban } \\
\text { neighborhood where he has lived for more than thirty years. }\end{array}$ & 2.8 \\
\hline Dottie X. & 1930 & $\begin{array}{l}\text { Mother of Barb E. Grew up in Lawrenceville, an inner-city } \\
\text { working-class neighborhood. Now lives in a wealthier suburb } \\
\text { but still identifies with Lawrenceville and often visits her } \\
\text { daughter Barb, who lives there. Did office work for her } \\
\text { husband's construction business; now retired. }\end{array}$ & 2.7 \\
\hline Arlene C. & $\begin{array}{l}\text { ca. } 1940 \\
\text { (declined } \\
\text { to give her } \\
\text { exact age) }\end{array}$ & $\begin{array}{l}\text { Grew up in a working-class steel town with her mother and } \\
\text { grandmother; has lived in Forest Hills, a white-collar } \\
\text { suburban neighborhood, for } 30 \text { years. Has held a variety of } \\
\text { administrative jobs, was the first woman on the local } \\
\text { borough council, and has been very active in neighborhood } \\
\text { organizations. }\end{array}$ & 1.3 \\
\hline Barb E. & 1957 & $\begin{array}{l}\text { Daughter of Dottie X. Was raised in a working-class suburb, } \\
\text { moved to Lawrenceville, the inner-city working-class } \\
\text { neighborhood where her mother grew up, in part because } \\
\text { she could afford to buy a house there. Works as an } \\
\text { administrative assistant to a university vice-president. }\end{array}$ & 1.2 \\
\hline Jessica H. & 1979 & $\begin{array}{l}\text { Grew up in Forest Hills, a white-collar suburban } \\
\text { neighborhood. After graduating from a Catholic university } \\
\text { in the Midwest, she returned to Pittsburgh, where she lives } \\
\text { with her parents and attends law school. }\end{array}$ & 1.3 \\
\hline
\end{tabular}

mother and daughter (interviewed together), whose accounts of the roles of regional speech in their lives differ in predictable but still very interesting ways; 2 are long-time acquaintances (interviewed together), whose accounts differ in ways that might be linked to gendered aspects of their life experiences (though we do not have room to pursue this thread here). The 5 speakers also represent the range of variation in local speech, as measured by "index scores" for the pronunciation of the vowel /aw/. ${ }^{3} \mathrm{~A}$ speaker with an index score of 3 would be using the local, monophthongal variant of (aw) 100 percent of the time; a speaker with an index score of 1 would be using the diphthongal variant 100 percent of the time. Thus, the higher the index score, the more nonstandard, working-class, and/or local-sounding a speaker could be taken to be, by someone to whom monophthongal /aw/ indexed correctness, class, or localness; to someone hearing diphthongal /aw/ as the standard variant (as would most Americans), a speaker with a lower index score would sound more standard and/or less local. Table 2 provides a demographic and linguistic sketch of each of the speakers. 
Figure 1

\section{Accurate Representation of the Multiple Dialect Boundaries in the Pittsburgh Area}

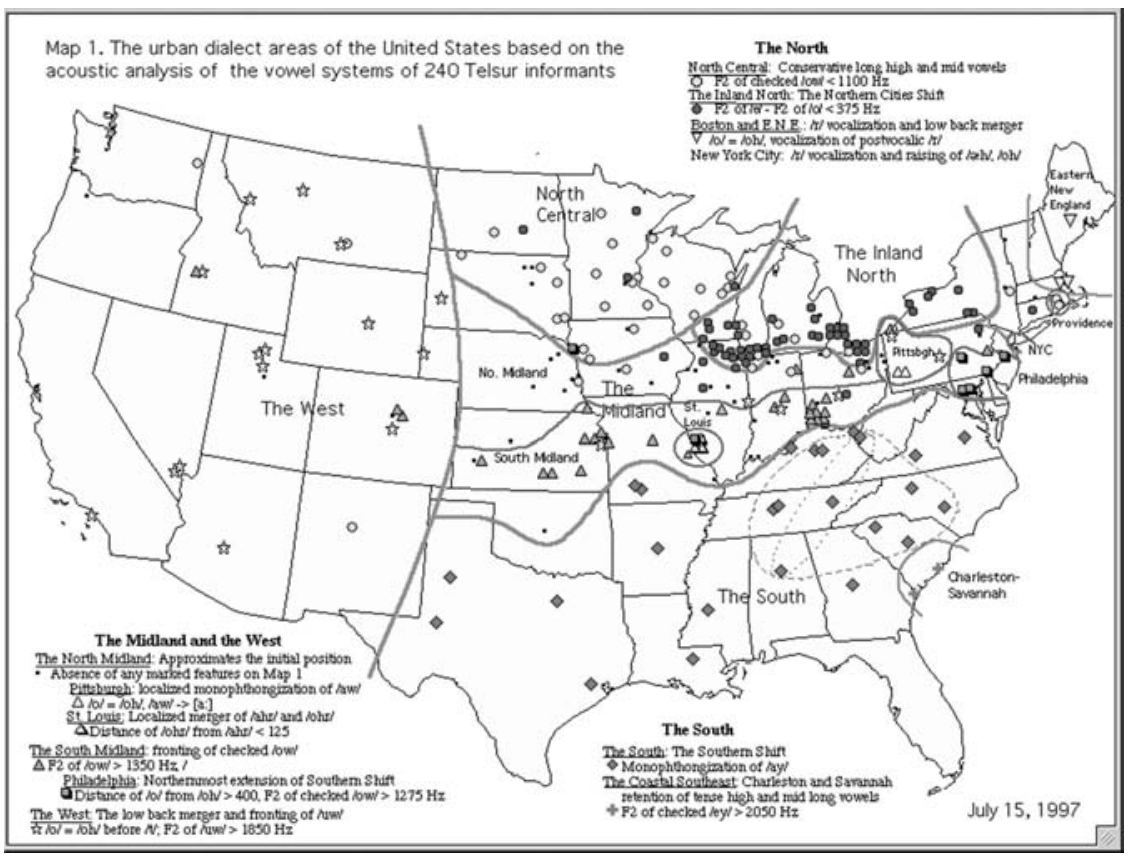

Source: http://www.ling.upenn.edu/phono_atlas/NationalMap/NatMap1.html. Used with permission. Note: For an updated view of the entire United States, see Labov, Ash, and Boberg (2005).

\section{The First-Order Situation: Preconditions for Dialect Enregisterment in Southwestern Pennsylvania}

The fact that Pittsburgh is located at the edges of the North and South Midland and Appalachia means that there is a large number of sounds, words, and structures that sound nonstandard and can be heard in this area (see Figure 1). Simply by virtue of distributional facts, these features are potential first-order indexes, in Silverstein's sense, of geographic location. A dialectologist using a word list to elicit regional pronunciations (Kurath 1949) could describe the link between speakers' location or place of origin and the occurrence of these features in people's speech, for example. In Labov's terms, they are indicators, hearable by linguists and correlated with geographic region. Research by Labov, Ash, and Boberg (2005) showed that there is a set of co-occurring phonological characteristics (merger of $/ a /$ and $/ \mathrm{s} /$, fronting of 
/o/, monophthongization of /aw/, and "Canadian shifting" involving several vowels) that distinguish an area in western Pennsylvania that includes Pittsburgh from other phonological dialect areas in the United States. Other scholarly research about varieties of English spoken in Pittsburgh and southwestern Pennsylvania (Kurath 1949, 35-36; Kurath and McDavid 1961, 17-18; Hankey 1965, 1972; Brown 1982; Gagnon 1999; McElhinny 1999; Johnstone, Bhasin, and Wittkofski 2002; Kiesling and Wisnosky 2003; Johnstone et al. 2004) identifies other phonological, lexical, and morphosyntactic features whose geographical distribution is limited and includes Pittsburgh. Phonological characteristics include a rounded or backed realization of the merged low back vowel, monophthongization of /ay/ before /1/ and /r/, laxing of tense vowels /i/ and /u/ before /r/ and /l/ (so that steel can be realized as [strl]), intrusive $[\mathrm{r}]$ in some words, and the vocalization of /l/. Lexical items identified with the region in the Dictionary of American Regional English (Cassidy 1985, 1991, 1996; Hall 2003) are almost all traceable either to Scots or Scotch-Irish usage or were originally trade names for things produced locally. They include, in the former category, to jag for to tease, nebby for nosy, slippy for slippery, and redd up for clean up; and, in the latter, gumband for rubber band, jumbo for bologna sausage, and chipped ham for thinly sliced ham. Morphosyntactic characteristics include reversed transitivity in leave and let (so that one might "leave the children go out" or "let the bags on the table"), the use of yinz (derived from you'uns) as a second-person plural pronoun, and the needs/wants + past participle construction represented in this shirt needs ironed or the customer wants served. Prosodic/discoursal features thought of as sounding local include final falling rather than rising intonation on some yes/no questions and the discourse-marking sentence-final use of $n$ 'at, with a meaning like "and stuff like that" or "and so on."

All of these features are limited in geographical distribution in one way or another, but none are heard only in Pittsburgh or in the Pittsburgh metropolitan area, although monophthongal /aw/ seems to be limited to a fairly small area (Johnstone, Bhasin, and Wittkofski 2002). Most features of pronunciation that sound local to Pittsburghers are widespread in central and western Pennsylvania, if not throughout the United States, and some of the lexical and morphosyntactic features thought of as local can be heard throughout the Ohio Valley or the Midland, Southern, and/or Appalachian dialect areas.

Along with the availability of nonstandard features that could potentially be heard as local, local social and economic history created additional preconditions for the emergence of "Pittsburghese" (Modell 1999; Oestreicher 1989; Lubove 1969; Hays 1989). Until World War II, Pittsburgh was relatively isolated. Many European immigrant languages were spoken in the city, but working-class Pittsburghers had little contact with anyone who spoke English differently than they did. Dense, multiplex social networks strengthened local dialect norms (Milroy 1987), and the fact that Pittsburghers had inherited a Scotch-Irish-influenced dialect that could be heard as distinctive was almost never brought to their attention. 
Historical and sociolinguistic evidence suggests that before the 1960s, the use of regional speech forms was correlated with social class and with localness, but the potential, first-order indexicality of these forms was rarely brought into second-order play. The connection between nonstandard speech forms and social identity was implicit. While regional speech features could index class identity for some people (and to some people), many sounded like working-class Pittsburghers because they had no other way to sound. People growing up in working-class families lived in insular neighborhoods within walking distance of the steel mills and other factories where their parents worked, and they went to school and church with their neighbors. These dense, multiplex sociolinguistic networks gave them access to regional dialect features and little opportunity to become aware that they spoke differently from people elsewhere, that some people would consider the way they talked nonstandard, or that the use of nonstandard features varied with socioeconomic class. Because the usage of regional forms was correlated, in some Pittsburghers' experience, with class, adopting an attitudinal or affiliative stance toward or against working-class identity could involve adopting or not adopting regional forms, but this option was open only to those whose repertoires included both regional and supraregional variants, and the kinds of social and geographical mobility that would give rise to varied linguistic repertoires were available to relatively few people.

Dottie X., born in 1930 and raised in the Irish ward of the inner-city neighborhood called Lawrenceville, reflected on this in the interview. Dottie uses the geographically regional monophthongal variant of /aw/ almost invariably, with an index score of 2.7. (By "geographically regional," we mean "regional" in a first-order correlational sense.) Dottie grew up in a neighborhood that she identifies as working-class, but the correlation between being working-class and using geographically regional speech forms was not talked about, joked about, or even noticed. "Everyone would have spoke the same, I guess," as she put it. Remarking further on her formerly nonreflexive use of regional variants, Dottie goes on to say that she "never even heard" a form she and others used regularly, the second-person plural pronoun yinz.

(1) Dottie X. and Barb E.: interview $5^{4}$

20 Dottie X. And I never even like, I guess I just, when I hear the word yinz, I mean I never even heard that. I mean, maybe I did, but there were, everyone said it, so I never thought anything of it or something like that. But now, people are like, "Yinz!", and I'm like, "Well so what?"

21 BJ

22 Dottie X. So you grew up saying that, and everybody else did. /I guess/

/Well maybe

they did and I don't know./ It just doesn't faze me. What's the, what's the big deal?

Dottie describes her neighbors in retrospect as having had an accent, but because the people she came into contact with on a daily basis sounded the same ("everyone said it"), she did not notice it. To put it in Agha's (2003) terms, forms like yinz and 
monophthongal /aw/ had not yet been enregistered. If local speech went hand in hand with being working-class, nothing in Dottie's environment pointed out the connection. Now, she suggests, people notice local-sounding forms like yinz ("people are like, 'Yinz!'”) but for Dottie, sounding like a working-class Pittsburgher is not, as she puts it, a "big deal." Responding to the implicit discourse of correctness that motivates and draws on the semiotic linkage between regional forms and social class that became available later and that motivates "people" to sound shocked by the use of regional forms, Dottie uses her personal history to construct an evaluatively neutral link between regional speech and class.

\section{Social Mobility and Second-Order Indexicality}

As features that can be heard in the speech of working-class Pittsburghers were taken up as sociolinguistic resources, first-order geographically regional features acquired social meaning, coming to do second-order sociolinguistic work connected with correctness, class, and place. In other words, some of Labov's "indicators" become "markers." This became possible in the context of social mobility, which gave Pittsburghers access to new variants of forms that had been relatively invariable in their speech or that of their neighbors. Once forms became variable, the choice among variants could, for some people, be invested with second-order indexical meaning such as class or correctness.

Dr. John K., born in 1928, was the son of a firefighter and grew up in a solidly working-class part of the city. Like Dottie X., John K. was not aware in his youth of the possibility that others might think he sounded as if he was from Pittsburgh or working-class, and he is still completely unaware that he has what others might consider a local accent. John monophthongizes /aw/ almost invariably in his own speech, as his index score of 2.8 for this variable indicates, but when asked to comment on alternative pronunciations of the word house ([haws] and the more local-sounding monophthongized [ha:s]), he associated the monophthongized version with people from elsewhere, claiming never to have heard it in Pittsburgh. In the extract that follows, the recorded voice is on a recording played for John K. and Arlene C., who were interviewed together, which contained the prompts for an experimental task meant to elicit participants' senses of the indexical meanings of variants of a number of sociolinguistic variables. In discussing the prompt and answering the ensuing questions, John K. and Arlene C. explicitly link regional speech with social class and education and explicitly deny that it can index local identity.

(2) John K. and Arlene C.: ha:s

1 BJ ((recorded voice)) Sentence 8. a. We bought a [haws]. We bought a [haws]. b. We bought a [ha:s]. We bought a [ha:s].

2 Arlene C. We bought a what? 


$\begin{aligned} 3 & \text { John K. } \\ 4 & \text { Arlene C. } \\ 5 & \text { John K. } \\ 6 & \text { Arlene C. } \\ 7 & \text { John K. } \\ 8 & \text { BJ } \\ 9 & \text { John K. } \\ 10 & \text { Arlene C. } \\ 11 & \text { BJ } \\ 12 & \text { John K. } \\ 13 & \text { Arlene C. } \\ 14 & \text { John K. } \\ 15 & \text { Arlene C. }\end{aligned}$

16 BJ

17 John K.

18 Arlene C.

19 BJ

20 Arlene C.

21 BJ

22 Arlene C.

23 John K.

24 BJ

25 John K.

26 BJ

27 Arlene C.

28 BJ

29 John K.
A [ha:s].

[ha:s]

A [ha:s].

[ha:s] ((sigh))

A [haw-], [haws] and a [ha:s]

So you can tell, you can hear a difference.

Oh my God yes.

$\mathrm{Mm}$ hmm.

Does one of them sound more correct than the other?

[haws] is more correct than [ha:s]

((laughing)) It's not-

[ha:s], that sounds like Brooklyn or /something/

/Or some-/ yeah. Or

Southside, somewhere.

/Yeah/.

Southside. ((to John K.)) So, does that- So to you it sounds more Pittsburgh? [ha:s] than [haws]?

I've never heard of [ha:s]. /Not here ( )/. Not anywhere in Pittsburgh, I never heard that. I heard it in Brooklyn.

\section{/I don't know./}

$\mathrm{Mm}$ hmm. So, you wouldn't say it sounds more Pittsburgh?

No.

((to John K.)) You wouldn't either. ((to both)) Does it sound more working-class?

/Ohh/

/Than [ha:s]/? Why yeah, it has to be.

Yeah, okay.

They didn't go to school or else they didn't learn.

Mmm hmm.

Or the teacher talked that way.

Or the teacher talked that way.

That's right.

Although he was socially mobile, eventually earning a $\mathrm{PhD}$, owning a medical laboratory, and living in a white-collar suburb, John had little reason to distance himself from potentially local-sounding forms, and thus little reason to notice or talk about them and little control over the choice of variants. In line 23 of the extract above, he produces [ha:s], apparently intended as an instantiation of /haws/. In response to the question about whether the variant [ha:s] "sounds more working-class," John queries, "Than [ha:s]? Why, yeah." It seems likely that he means that [ha:s] sounds more working-class than [haws], but because the monophthongization is not controllably variable in his productive repertoire, he produced [ha:s] instead. Particularly for men, using local speech forms can carry covert prestige (Trudgill 1972) locally, so that even the best-educated professionals of John's generation have Pittsburgh accents, and during John's travels 
to conferences and trade shows, nobody ever commented on his accent, as he said elsewhere in the interview. (Many Pittsburghers tell stories about being recognized as Pittsburghers because of their accent, or at least having had it commented on when they were elsewhere [Johnstone forthcoming-b], but John K. explicitly denied ever having had such an experience.) As a result, the indexical link between features like /aw/-monophthongization and social identity is a first-order link in John's speech production: he uses regional features because he is, in a demographic sense, from the region, not to express second-order indexical meaning. When asked explicitly to reflect on the potential second-order indexicalities of the monophthongal variant of /aw/, John labels it as working-class and adds that it signals a lack of education ("They didn't go to school or else they didn't learn," 1. 25), but he does not hear it as a local form.

For Arlene C., with whom John was interviewed, sounding local was a social liability, on the other hand (as is suggested by her sigh in line 6), and Arlene accordingly has productive control of variable features that, for her, are second-order indexical markers of class and incorrectness. With a working-class upbringing and an upwardly mobile professional, marital, and residential trajectory, Arlene exemplifies the upper-working-class pattern of hypercorrection described by Labov (1972a). She monophthongizes /aw/ at a much lower rate than does John K., using the supralocal, diphthongal variant at the same rate as women two generations younger than she. Arlene is very sensitive to class differences, which (adopting a common strategy in Pittsburgh) she often points to through references to neighborhoods. In extract (2), for example, she identifies local speech with "the Southside," a working-class neighborhood. She identifies herself with the white-collar neighborhood she lives in now, preferring the awkward neologism "Forest Hillian" to "Pittsburgher" when asked earlier in the interview for a list of words reflecting her sense of identity. If regional speech forms can now index local identity as well as social stigma, Arlene does not hear them that way, answering "No" when asked whether monophthongal /aw/ "sounds more Pittsburgh" than the diphthongal variant.

Like Arlene C., many interviewees continue to link regional speech forms to incorrectness. In extract (3), for example, Dottie X. and her daughter Barb E. talk about an accent-reduction course Barb has read about. Like Arlene, they use neighborhood names to encode class distinctions and draw on the potential linkage of local-sounding forms with incorrectness to construct a negative linkage between local speech and social class. Thus people who do not "speak correctly" must be "from Lawrenceville," and such people are candidates for accent reduction classes because they risk "misrepresenting" the companies they work for.

(3) Dottie X. and Barb E.: interview 5

4 Barb E. Yeah. There was an article in the Business Times a couple weeks ago about a- I guess it's a consulting firm, I think. Where they will, if you had a company, and you were hiring employees. They would go into your company, and sort of counsel people on how to speak correctly, so that they wouldn't misrepresent the company, if you have= 
5 Dottie X. =So they wouldn't know that you were from Lawrenceville.

6 Barb E. Yeah.

7 Dottie X. So, 'cause they always say that Lawrenceville, they don't like the accent. The way people, you know. Their terminology, I guess the way they speak, you know, they ( ) must be from Lawrenceville.

8 BJ Yeah. Uh huh.

9 Barb E. Yeah.

As she suggested in extract (1) above, Dottie spent most of her life unaware of the value others might associate with the way she spoke, because she was not in social contact with many people for whom local speech features could carry second-order indexical meaning. Becoming aware that she speaks with a nonstandard accent has required learning to hear regional forms as nonstandard and as a socially stigmatized "accent." Dottie's daughter Barb, who grew up with an awareness that regional forms can index a stigmatized class-based identity, talks about how their use can also signal social solidarity. This can be seen in extract (4), where Barb talks about talking differently (i.e., using more regional forms) with a university maintenance worker ("someone in the service response center") than to "the assistant to the President" of the university. If she "knows it's a Pittsburgher" she is talking to and "they're talking to me in that sort of colloquial kind of 'this is how we talk," "then regional-sounding speech is appropriate. "I don't think it's a judgmental thing," as she puts it.

(4) Dottie X. and Barb E.: interview 5

29 Barb E. And I will say this too. I think working in my job, I think there are certain people that I interact with that I, um, I will talk a little bit differently with them, just to, so that they'll feel, feel comfortable with me. But I think that goes back to, like I said earlier about what I do, and how I interact with all different kinds of people. I think that you, and I don't think it's a judgmental thing. I think it's just you should be aware of, you know, who you're talking with and you know sort of what their expectations are and what their perception of you is going to be. So, if I am talking with some one in the service response center about needing a light bulb, I'm going to talk differently than I'm going to talk to the assistant to the president. Yeah, I mean it's just, you know. And if it's, if I know it's a Pittsburgher and they're talking to me in that sort of colloquial kind of 'this is how we talk' then that's, yeah, that's you know, that's how we talk.

Unlike her mother, Barb E. came of age in an environment in which using regional forms could have second-order social consequences; it could create social solidarity with fellow Pittsburghers via its potential to index locality, but it could also index class, occupation, or level of education. 


\section{Geographic Mobility and Third-Order Indexicality}

In the post-World War II decades, the second-order indexicality of certain features (their potential to mark, in Labov's sense, correctness, class, and locality) itself became usable. While the second-order indexicality of these forms continues to make them hearable and usable as markers of social class, education, and local life experience, the fact that these features could be used these ways became more and more salient. This occurred through metapragmatic practices that selected a subset of the forms that can do second-order indexical work, linking this subset to a more stabilized social identity and making these forms available for self-conscious, performed identity work. The raw material for second-order sociolinguistic "marking" is the existence of first-order correlations, which, filtered through ideologies about connections between correctness and class, become resources for hearing other people's class and education level and projecting one's own. The raw material for third-order identity work is second-order stylistic variability, which is filtered through more abstract ideologies about what dialects are and how they are linked to identities. At this stage, people notice that people with more stereotypical Pittsburgh identities have less variable, more regional-sounding accents, and attribute this to an essential connection between place and language. In the process, this subset of nonstandard forms has come increasingly to index localness and less, or more indirectly, class. While they continue to do second-order work as well, regional forms are now increasingly heard as signals of authentic local identity and can be used to project localness. Many of the metapragmatic practices that have made this possible have been metadiscursive, involving explicit talk about talk. Some "markers," in other words, have become "stereotypes."

During World War II, many working-class Pittsburgh men were geographically mobile, traveling in the military, and the mostly unionized industrial workers in the post-World War II years made enough money to vacation at East Coast beaches and elsewhere, where they interacted with people who sounded different and noticed how the Pittsburghers sounded. Demographic change at home also helped create the conditions for talk about local speech. During the 1960s and 1970s, the "baby-boom" grandchildren of the immigrant industrial laborers who had arrived between 1880 and 1920 began to come of age, no longer speaking the homeland language and with weakened ties to immigrant religions (Oestreicher 1989, personal communication). While their parents and grandparents thought of themselves mainly in ethnic or religious terms (as Polish, for example, or Eastern Orthodox), these Pittsburghers began to develop class and regional consciousness. We do not have space to go into this shift in detail here, except to note that this new kind of working-class youth identity was taken up in the popular media of the time. For example, the plot of Michael Cimino's 1978 film The Deer Hunter, set in a Pittsburgh-area steel mill town, ties the older generation to the Russian Orthodox church and immigrant traditions and the younger generation to the 
mountainous local topography and a western Pennsylvania way of life represented by deer hunting. The ground was fertile for ways of imagining what it meant to be a working-class Pittsburgher, and the existence of variable regional pronunciations that could index class and place, forms that people elsewhere heard as different and Pittsburghers elsewhere identified with home, provided an easily available resource for doing this.

Pittsburgh's economic upheaval of the 1970s and 1980s meant vastly increased geographical mobility and resulted in new kinds of talk that led to dialect leveling, at the same time as it led people to link dialect and social identity more explicitly. When local steel production was moved to areas where labor was cheaper, people whose families had lived in Pittsburgh for generations were forced to relocate to find work. Displaced Pittsburghers who visited or eventually moved back brought with them stories about being told they sounded funny (Johnstone forthcoming-b), and nostalgic talk about Pittsburgh and Pittsburgh speech became common in diasporic communities of Pittsburghers (Johnstone and Baumgardt 2004). New opportunities for talk about talk meant that Pittsburghers became increasingly aware that features of their speech were local in geographic distribution and noticeable to others, and the potential for indexical linkages between local forms and social identities was increasingly made explicit. The largest wave of out-migration occurred in the 1980s, with the final closure of most of the local steel mills, but the population continues to shrink as young people who would like to stay often cannot find work.

Working-class Pittsburgh neighborhoods are less homogeneous than they once were, and many formerly monoethnic neighborhood churches and parochial schools have been merged. Together with public school efforts at greater racial integration such as specialized "magnet schools" meant to draw enrollment citywide, this means that young Pittsburghers now come into contact with people who are unlike them at a much younger age than before. Thus even among people who have not (or not yet) left the city, conditions are conducive to the discursive practices that give rise to explicit talk about the second-order indexicality of certain forms. The medical and university sectors of the economy have also grown, attracting students and professionals from elsewhere. The availability of inexpensive housing, studio, and office space in former industrial neighborhoods means that young artists, designers, musicians, and other "creatives" can stay in the city after graduating from local universities. These people notice regional speech features, now as often in mass media representations like folk dictionaries and Web sites that metapragmatically link regional speech and local identity as by actually interacting with locals engaging in metapragmatic practices that link local forms with class and correctness. They use them in reflexive, self-conscious attempts to claim local identity by displaying local knowledge.

On the stage set by the second-order indexicality of certain local speech features, discursive practices and artifacts have emerged that have enregistered local speech in the local imagination as unique and unchanging and have strengthened and stabilized the ideological links between local speech and place, making other indexicalities less 
and less available for identity work. An extended example of a discursive process in which "Pittsburghese" has been semiotically de-linked from class and linked with place in metadiscursive talk is provided by a Carnegie Library of Pittsburgh archive of materials about Pittsburgh speech published between 1910 and 1997. ${ }^{5}$ Analysis of twenty newspaper articles that are from Pittsburgh publications and that discuss pronunciation, lexical, and grammatical features described as characteristic of local speech $^{6}$ shows that stories calling attention to linguistic differences between this area and others, which have appeared sporadically since at least 1910, became much more frequent in the post-World War II years, beginning in the 1950s.

Of the newspaper articles about local speech that began appearing regularly during the 1950s and 1960s, a large majority were feature articles, many appearing in the Pittsburgh Press's Sunday Magazine section, segregated from the "real" news and accompanied by cartoon illustrations. These early articles generally isolate and describe features of regional speech, treating them by and large as curiosities. Local speech is characterized almost exclusively in a disparaging way. Evaluative phrases like "my favorite speech oddity" (Bernhard 1959), "the nasal way of talking" (Gleason 1965), and "a distinct impression of ignorance" (Swetnam 1959) make it clear that examples of Pittsburgh speech are meant to be taken as amusing but undesirable irregularities. Another way in which Pittsburgh speech is presented as an object of reproach is through the use of "eye-dialect" spellings in several articles. These evaluative moves serve to strengthen potential semiotic links between local speech and socioeconomic class.

Local curiosity about local speech coincided in the late 1960s and early 1970s with the willingness of a University of Pittsburgh dialectologist, Robert Parslow, to legitimize these forms in interviews by explaining their history and referring to them in the aggregate as a dialect. The term "Pittsburghese" first appears in a Pittsburgh Press Sunday Magazine article published in 1967 (Gleason 1967). The article's title, "Strictly Pittsburghese: Only in Western Pennsylvania Do You Hear 'Gum Band' and 'Needs Washed,' " makes an explicit (if inaccurate) link between locally heard forms and place. This is the first article in the archive to feature quotations from Parslow. Aside from debunking the notion that Pittsburgh dialect has roots in Pennsylvania German (a notion that the article implies was common at the time), Parslow also referred to the Linguistic Atlas project for the region (McDavid et al. 1980). Parslow is quoted extensively throughout the article, discussing the place of Pittsburgh speech in the Midland dialect region as well as the historical background of the Northern U.S. dialect region.

The inclusion of testimony by a dialectologist marks the beginning of a shift away from treating locally hearable speech forms exclusively as somewhat objectionable curiosities and toward enregistering and legitimizing a set of these forms as "Pittsburghese," a "dialect" linked explicitly, via its name, with place. Of the twelve articles in the archive that appeared after 1967, nine feature some sort of "expert" testimony, from Parslow, fellow University of Pittsburgh linguists, a Carnegie Mellon University English professor, local teachers, and Frederick Cassidy, the editor of the 
Dictionary of American Regional English. Local speakers' attitudes are also increasingly solicited, and the possibility that the local way of talking may actually be appropriate in some situations begins to be broached. The term Pittsburghese comes to be used without quotation marks, and reporters treat it as a regional rather than a social variety, sometimes by making the explicit claim that it is. For example, the headline of a 1973 article (McGough 1973) is "Pittsburghers Have a Dialect All Their Own." These trends have continued since the archive's close in 1997, with a 2001 article about the Pittsburgh Speech and Society project (Pitz 2001) prominently featuring the project's codirector Johnstone in a picture and in the text and citing research statistics. The article makes repeated enregistration moves, discussing local forms as a dialect and linking the dialect explicitly with place by identifying it as "Pittsburghese" throughout, describing it as "the talk of the town" and "the city's distinctive dialect" and pointing out that it can be a marker of local identity and a source of pride. A sidebar contains a list of "Pittsburghese" words taken from the jokey, nonacademic www .pittsburghese.com Web site (see below) with their definitions.?

Through the metadiscursive activities represented in the newspaper archive, "Pittsburghese" begins to acquire legitimacy. As it is talked about repeatedly in the same or similar ways, it also becomes increasingly standardized. The same words, sounds, and structures are mentioned again and again. The orthography of "Pittsburghese" has also tended to become more and more consistent over time. In the archive corpus, the regional second-person plural pronoun is spelled variously as $\langle$ yinz $>,<$ y'nz $>$, $<$ you-ns $>$, $<$ you-uns $>,<$ yuhnz $>,<$ yunz $>$, and $<$ you-unz $>$. The trend over time has been for spellings that represent the morphological structure and etymology of the word, like $<$ you-uns $>$, to be replaced with increasingly phonetic spellings, such as <yuhnz $>$, $<$ yunz $>$, and $<$ yinz $>$, erasing traces of the local form's similarity to and historical connection with forms used elsewhere.

During the same years, many other metadiscursive activities have also contributed to the enregisterment of "Pittsburghese." A folk dictionary titled Sam McCool's New Pittsburghese: How to Speak Like a Pittsburgher (McCool 1982) was first published in 1982 and has been in print ever since (Johnstone 2005). As its title suggests, How to Speak Like a Pittsburgher highlights the ways in which regional speech can index local identity, linking the dialect with place, but its contents and illustrations also draw on linkages between local forms and class and gender, with pictures and examples drawn from working-class-male imagery. How to Speak Like a Pittsburgher has served as a source for T-shirts, coffee and beer mugs, shot glasses, refrigerator magnets, and postcards listing local speech forms. Many of these recycle its spellings and definitions and the visual motif of its cover, on which forms thought to be local are juxtaposed on the city skyline. Such artifacts are less likely than the McCool book to make implicit references to class, and they tend to be sold as souvenirs of the city, which further links dialect and place.

Young adults who left Pittsburgh in the 1980s to find work are now middle-aged, and the combination of their nostalgia for their hometown and their computer literacy has created the conditions for online metadiscursive talk among people who are widely dispersed. These discussions also help enregister the dialect and link it with place. 
A very popular 1990s Web site, www.pittsburghese.com, offered anyone with Internet access the opportunity to engage in a folk-lexicographic activity, the posting of forms thought to be local with definitions and examples. (The site was mounted and maintained by a marketer who hoped to use it to advertise Pittsburgh-related products; it is still accessible as of May 2006, though no longer interactive.) In a study of another online activity, Johnstone and Baumgardt (2004) showed that rhetorical demands on contributors to a 2002 online discussion about whether local speech is "charming or embarrassing," notably the need to display authentic Pittsburgh identities to project epistemic authority, favor activities like mentioning and defining local speech features in a lexicographic way, and contributors' nostalgia favors forms they associate with place. (The discussion was hosted by a TV station on its Web site as a follow-up to a news item about a workshop about Pittsburgh speech that Johnstone and coinvestigator Kiesling had organized; it thus provides another example of the ongoing role of linguists in the process we describe in this article.)

Unlike their parents, many middle-class Pittsburghers who are now young adults grew up knowing about "Pittsburghese," and they use it in stylized performances of local identity (Johnstone forthcoming-a). While working-class Pittsburghers continue to use regional forms in everyday speech, this middle-class generation sounds more supralocal. Most, for example, do not use the regional form yinz either as a first-order only choice or as a second-order variable. But this generation has embraced the term yinzer, a noun derived from yinz designating someone with a strong local identity and local accent. Ethnographic evidence suggests that yinzer may have been coined by high school students in the late 1960s, but it was understood as exclusively derogatory and not widely heard until the 1990s, when it began to be used in a more ironic, polysemic way by people aspiring to urban hipness. For example, a literary magazine founded in the early 2000s was entitled The New Yinzer (in typeface like that of The New Yorker).

Jessica H., who was twenty-five when we spoke to her in 2004, represents one of the ways the stabilized set of ideas about local speech and local identity that have circulated since the 1980 s can be deployed in third-order place identity work. Jessica grew up with relatively little exposure to people with strong regional accents but with an explicit awareness of "Pittsburghese." (She remembers seeing T-shirts and other written representations of the dialect in childhood.) Jessica H. does not claim local speech as central to family, community, or personal identity. During the interview, she narrated "one of the biggest games from freshman year," her first year at a university in different part of the United States that draws students from all over the country. The game involved performing and comparing regional accents.

(5) Jessica H.: dahn

1 Jessica $\mathrm{H}$. It was the first opportunity that I had to be out of the area for an extended period of time. An- and, I mean, my, my close friends from school, from X University were from New Jersey, New York, Buffalo again, Chicago, um, all over.= 
2 BJ

3 Jessica $\mathrm{H}$.

$4 \quad$ BJ

5 Jessica $\mathrm{H}$. =It was like different colloquialisms and that kind of thing. Um, it was interesting. $=$

6 BJ =Were there really big differences, or=

7 Jessica H. =Um, my, my friend from New Jersey, she was from South Jersey near Philly, and, had a pretty serious South Jersey accent, so that was a fun one. Um. There was people with, with New York accents. And then there was a group of us actually who were from Pittsburgh, and got picked on for our Pittsburgh accents as well. /So, it was interesting./

8 BJ $/(($ laughs $))] /$ What were- what did people say? I mean, what didwhat did they notice?

9 Jessica H. Um, “down," a lot of that, you know. Um. Just, A's were a big thing. /You know, "down"s/ the-

10 BJ /Uh huh. The [aw]s/

11 Jessica H. Yeah exactly. No, no one said "yinz" or anything like that. Except in jest, but um, it was, yeah=

12 BJ =It's interesting that people would notice. /You/ know, you don't have a really strong local accent compared to some people, but-

13 Jessica $\mathrm{H}$.

it was significant enough them to notice, though. An- and you think in a educa- in an educational setting it sort of goes away, everybody sort of blends together, but, it- there were still some words /that/ everybody picked out pretty quickly, so=.

14 BJ

15 Jessica $\mathrm{H}$. =Mm hmm, $\mathrm{mm} \mathrm{hmm}$.

The dialect-comparing activity Jessica describes occurs at a time when identity talk is at a premium, as new university students get to know their classmates. It draws on and reinforces the idea that dialect and place are essentially linked: accents are treated as automatic consequences of people's places of origin. (The idea that dialect could index other aspects of social identity, such as class, does not arise and would probably derail the activity if it did.) In this activity, regional accents apparently consist of features drawn from the kinds of lists found in folk dictionaries and on T-shirts. The features of Pittsburgh speech Jessica describes in answer to the interviewer's question about what the other students "noticed" are the ones that are the most common in third-order media representations of local speech (Johnstone, Bhasin, and Wittkofski 2002): monophthongal /aw/ in the word down, the pronoun yinz, the term pop for a carbonated soft drink. Neither monophthongal /aw/ nor yinz is actually a feature of 
Jessica's un-self-conscious speech, nor are they variable features that do second-order indexical sociolinguistic marking in her speech (although they may serve this function when she listens to others' speech). In this environment, where accents are "fun" and not linked with social class, it is no longer the variable, second-order use of regional variants in everyday interaction, but third-order performances of a person's knowledge of the sociolinguistic stereotypes that constitute "Pittsburghese" that are used to index region, in the self-conscious construction of social identity.

\section{Discussion}

We have shown how, in the process through which "Pittsburghese" has been enregistered, the primary potential indexicality of local speech has shifted from class to place. Rather than assuming, as is done in a great deal of work in dialectology and variation studies, that dialects and varieties can be mapped onto places, we have treated dialect and place as cultural constructs (Johnstone 2004) and explored how they shape each other in speakers' imaginations. The emergence of "Pittsburghese" as a stable, dictionary-like list of words and phrases, and its emerging use in the making of explicit social identity claims, have gone hand in hand with the emergence of "da Burgh" as a place to identify with, and these processes have been driven in large part by economic change.

"Pittsburghese" is the outcome of the dialect-enregistration processes we have been discussing, but it is also a resource for these processes. Almost all the Pittsburghers we talked to have heard people using regional features, and they have used variability as an indexical resource in projecting social identities onto themselves and others. When we ask them about local speech, they usually think they are talking about their experiences with this second-order indexicality. But they have also read newspaper articles about local speech; almost all of them have seen a copy of How to Speak Like a Pittsburgher; when we asked about local speech, some produced coffee mugs or T-shirts bearing lists of "Pittsburghese" words and phrases to show us. Surrounded by multiple ways in which local speech can be meaningful, Pittsburghers draw on their experiences of first-, second-, and third-order indexicality as they decide how to talk and how to talk about talk. Thus, sociolinguists interested in understanding patterns of variation and change in the speech community need to pay attention not just to people's talk but to the metapragmatic activities in which they create and circulate ideas about how they talk.

In taking a historical approach to language attitudes, we have shown how our understanding of "stylization" (Hill 1995; Johnstone 1999b; Coupland 2001) is enhanced by exploring the processes through which the resources for such performances emerge, and how the ideas elicited in research on "folk linguistics" (Preston 1989; Preston and Niedzielski 1999) come to be. Understanding the geographical, linguistic, and historical contexts in which attention to and talk about dialect emerges and circulates enables 
interactional sociolinguists and students of folk linguistics to understand the ebb and flow of such activities over time.

Studies of larger-scale social processes such as globalization and commodification can benefit from juxtaposing analyses of cultural artifacts such as media discourse that circulate through communities with explorations of the experiences of individuals (Johnstone 1996, 2000a). The two-pronged approach we have taken in this article displays the linkage, usually assumed but not often described, between publicly circulating discourses about language and the linguistic life experiences of individuals. Paying attention to individuals also inevitably complicates the picture in interesting ways.

Finally, this article illustrates how notions of language standardization are productively complicated when we explore the standardization of vernacular varieties as well as that of prestige varieties. Explicit metadiscourse like that involved in the "complaint tradition" (Milroy and Milroy 1985) and many practices aimed at "verbal hygiene" (Cameron 1995) is the primary focus of Agha's (2003) analysis of the enregisterment of RP. Very similar kinds of explicitly normative talk have been involved in the enregisterment of "Pittsburghese" (Johnstone and Baumgardt 2004). But normative processes are also involved in less self-aware phases of change, as more implicit metapragmatic practices cause speakers to converge on shared ways of using variability to express and interpret indexical meaning. This is the point made by Labov in his characterization of sociolinguistic markers as "norms which define the speech community" (1972b, 179). As Cameron $(1995,9)$ put it, "The potential for [normativity] is latent in every communicative act, and the impulse behind it pervades our habits of thought and behavior." The idea of indexical order forces us to view through the same lens dialect-normative practices that we have traditionally considered separately, allowing us to see how these layers of normativity are connected.

\section{Appendix \\ Newspaper Articles about Pittsburgh Speech Used in This Analysis}

Bernhard, Andrew. 1959. Pittsburgh speech has its own differences. Pittsburgh Post-Gazette, December 14 , p. 2.

Bloom, Si. 1977. Every one talks funny but us. The Pittsburgher, August, pp. 39-40, 79.

Browne, Joe. 1976. Our towne. Pittsburgh Post-Gazette, December 20.

Carrell, Maud. 1910. Pittsburg's sayings and proverbs. Pittsburg Dispatch, December 12, p. 7.

Davidson, Jim. 1984. We'uns sure stretch the King's English. Pittsburgh Press, December 30, Sunday Magazine, p. 4.

Gleason, David. 1965. That's what you said. Pittsburgh Press, May 30, Sunday Magazine, p. 3. 1967. Strictly Pittsburghese: Only in Western Pennsylvania do you hear 'gum band,' and 'needs washed'. Pittsburgh Press, June 18, Sunday Magazine, p. 3.

Gray, James. 1968. Dialect in dilemma. Pittsburgh Press, July 14, Sunday Magazine.

Huzinec, Mary. 1977. Pitt prof finds Pittsburghese a slippy subject. Pittsburgh Press, November 21, p. A-2. 
Leo, Peter. 1982. This column needs read. Pittsburgh Post-Gazette, June 21.

Love, Gilbert. 1952. What we say. Pittsburgh Press, January 18, sec. 2, p. 23.

McGough, Michael. 1973. Pitsburghers have a dialect all their own. Pittsburgh Post-Gazette, October 15, Daily Magazine, p. 1.

McHugh, Roy. 1979. He scotches Pittsburgh monopoly on 'yunz'. Pittsburgh Press, September 9, p. A-2. Pitz, Marilynne. 2001. Patter, patois, or pidgin, it's the talk of the town. Pittsburgh Post-Gazette, February 11. Swetnam, George. 1959. Pittsburgh patois. Pittsburgh Press, September 6, Sunday Magazine, p. 4. 1970. Your talk tells tales. Pittsburgh Post-Gazette, October 15, Sunday Magazine, p. 10.

Warnick, Mark S. 1990. Lawrenceville aside, fewer of yunz speak Pittsburghese. Pittsburgh Press, July 15, p. H-1.

\section{Notes}

1. In the United States, Northern, Midland, and Southern varieties continue to differ, particularly in their vowel systems (Labov 1991), while distinctions among subregional patterns of variation shrink and once-isolated dialects become moribund.

2. For Labov (1972b, 179), the social meaning of a marker has spread throughout the speech community, so that "all members of the speech community reacted in a uniform manner to its use (without necessarily being aware of it)." Our focus is on speakers rather than on speech communities, however; for us, a feature is functioning as a marker if in a given instance it is heard as having social meaning or used to project such meaning.

3. All instances of the variable (aw) in each conversational interview were coded acoustically. Each token was given a score of 1 (clearly diphthongal), 2 (in between), or 3 (clearly monophthongal). To check validity and to add descriptive detail, a 169-token random-sample subset of the entire sample (consisting of all the neighborhood-study interviews, including these five) was analyzed instrumentally. Measurements were taken using the interval analysis function in Akustyk, an add-on to Praat. The acoustically measured tokens were then subjected to an ANOVA to test whether the categories of the auditory classification were valid for F1 and/or F2, which showed that the auditory classification was reliably measuring F2 differences (F: 22.001, $d f=2, p \leq 0.0001$ ).

4. In the transcribed extracts, we use normal orthography and punctuation as much as possible, for readability.

When phonetic transcription is necessary to capture aspects of speech that are relevant for our argument, we enclose it in [square brackets].

/Slashes/ enclose simultaneous speech, which is left-aligned.

Equals signs ( $=$ ) indicate that the second utterance follows immediately on the first.

Empty single parentheses ( ) indicate the presence of verbal material we could not make out.

((Double parentheses)) enclose transcriber comments about voice quality, gaze, or nonverbal sounds.

5. The archive consists of articles, books, and other printed material on the topic of Pittsburgh speech in the Pennsylvania Collection at the Carnegie Library of Pittsburgh. According to librarians at the Carnegie Library, Rose Demorest, the first head librarian of the Pennsylvania department, probably started the collection. The first newsprint clipping (as opposed to microfilm copy) is from 1952, making this the likely date that the file was created. The file consists primarily of newspaper and magazine articles, but it also includes several "Pittsburghese" glossaries, as well as excerpts from Kurath and McDavid's (1961) The Pronunciation of English in the Atlantic States. While a majority of the articles focus on pronunciation, vocabulary, and grammar, there are several articles on other language topics, such as issues surrounding Pennsylvanians whose first language is Spanish, local proverbs, and American African Vernacular English "slang." For a more detailed version of the analysis we present here, see Johnstone and Danielson (2001; Johnstone et al. 2004). 
6. We also include one article not currently found in this collection but from the personal papers of Dr. Robert Parslow, a linguist who studied Pittsburgh speech in the 1960s and 1970s, and one collected by Johnstone. We are grateful to Patricia Parslow, Parslow's widow, for making the former available to us. A list of the articles on which this analysis is based is provided in the appendix.

7. As was clearly the case for Robert Parslow, Johnstone's interview with the reporter influenced but did not determine what was said in the article. Johnstone talked about the role of local speech in performances of local identity and the pride some people have in it, but she urged the reporter not to use the term "Pittsburghese" and said that there were few if any strictly local forms, and she was not consulted about the sidebar list.

\section{References}

Agha, Asif. 2003. The social life of a cultural value. Language \& Communication 23:231-73.

Auer, Peter, Frans Hinskens, and Paul Kerswill, eds. 2005. Dialect change: Convergence and divergence in European languages. Cambridge: Cambridge University Press.

Beal, Joan C. 1999. "Geordie Nation": Language and regional identity in the north-east of England. Paper presented at Methods X (Tenth Conference on Methods in Dialectology), St. John, Newfoundland, Canada.

Bernhard, Andrew. 1959. Pittsburgh speech has its own differences. Pittsburgh Post-Gazette, December 14 , p. 2.

Brown, Cynthia. 1982. A search for sound change: A look at the lowering of tense vowels before liquids in the Pittsburgh area. MA thesis, University of Pittsburgh, PA.

Cameron, Deborah. 1995. Verbal hygiene. London: Routledge.

Cassidy, Frederic G., ed. 1985. Dictionary of American regional English. Vol. 1. Cambridge, MA: Harvard University Press.

— ed. 1991. Dictionary of American regional English. Vol. 2. Cambridge, MA: Harvard University Press.

— , ed. 1996. Dictionary of American regional English. Vol. 3. Cambridge, MA: Harvard University Press.

Coupland, Nikolas. 2001. Dialect stylization in radio talk. Language in Society 30:345-75.

Gagnon, Christina L. 1999. Language attitudes in Pittsburgh: "Pittsburghese" vs. Standard English. MA Thesis, University of Pittsburgh, PA.

Gal, Susan, and Judith Irvine. 1995. The boundaries of languages and disciplines. Social Research 62:967-1001.

Gleason, David. 1965. That's what you said. Pittsburgh Press, May 30, p. 3.

1967. Strictly Pittsburghese: Only in western Pennsylvania do you hear 'gum band,' and 'needs washed'. Pittsburgh Press, June 18, p. 3.

Hall, Joan Houston, ed. 2003. Dictionary of American regional English. Vol. 4. Cambridge, MA: Harvard University Press.

Hankey, Clyde T. 1965. Miscellany: "Tiger," "tagger," and [a] in western Pennsylvania; diphthongal variants of [ع] and [æ] in western Pennsylvania. American Speech 40:226-29.

- 1972. Notes on west Penn-Ohio phonology. In Studies in linguistics in honor of Raven I. McDavid, Jr., ed. L. M. Davis, 49-61. University: University of Alabama Press.

Hays, S. P., ed. 1989. City at the point: Essays on the social history of Pittsburgh. Pittsburgh, PA: University of Pittsburgh Press.

Hill, Jane H. 1995. Junk Spanish, covert racism and the (leaky) boundary between public and private spheres. Pragmatics 5:197-212.

Johnstone, Barbara. 1996. The linguistic individual: Self-expression in language and linguistics. New York: Oxford University Press. 
1999a. Lingual biography and linguistic variation. Language Sciences 21:313-21.

1999b. Uses of southern speech by contemporary Texas women. In "Styling the 'Other,' " ed. Ben Rampton, theme issue, Journal of Sociolinguistics 3:505-22.

2000a. The individual voice in language. Annual Review of Anthropology 29:405-24.

2000b. Representing American speech. American Speech 75 (Diamond Anniversary Essays): $390-92$.

- 2004. Place, globalization, and linguistic variation. In Sociolinguistic variation: Critical reflections, ed. C. Fought, 65-83. New York: Oxford University Press.

- 2005. How to speak like a Pittsburgher: Exploring the role of a folk dictionary in the production of a dialect. Paper presented at New Ways of Analyzing Variation, New York.

- Forthcoming-a. Linking identity and dialect though stancetaking. In Stancetaking in discourse:

Subjectivity in interaction, ed. R. Englebretson. Amsterdam: John Benjamins.

- Forthcoming-b. A new role for narrative in variationist sociolinguistics. In "Narrative Inquiry: State of the Art," ed. Michael Bamberg, special issue, Narrative Inquiry.

Johnstone, Barbara, Jennifer Andrus, Dan Baumgardt, Anna M. Schardt, and Scott Kiesling. 2004. Whose social meaning? Pittsburgh monophthongal /aw/ in perception and production. Paper presented at New Ways of Analyzing Variation (NWAV) 33, Ann Arbor, MI.

Johnstone, Barbara, and Dan Baumgardt. 2004. "Pittsburghese" online: Vernacular norming in conversation. American Speech 79:115-45.

Johnstone, Barbara, Neeta Bhasin, and Denise Wittkofski. 2002. "Dahntahn Pittsburgh": Monophthongal /aw/ and representations of localness in southwestern Pennsylvania. American Speech 77:148-66.

Johnstone, Barbara, and Andrew Danielson. 2001. "Pittsburghese" in the daily papers, 1910-2001: Historical sources of ideology about variation. Paper presented at New Ways of Analyzing Variation 30, Raleigh, NC.

Kiesling, Scott F., and Marc Wisnosky. 2003. Competing norms, heritage prestige, and the decline of /aw/-monophthongization in Pittsburgh. Poster presented at New Ways of Analyzing Variation 32, Philadelphia.

Kurath, Hans. 1949. A word geography of the eastern United States. Ann Arbor: University of Michigan Press.

Kurath, Hans, and Raven I. McDavid. 1961. The pronunciation of English in the Atlantic states. Ann Arbor: University of Michigan Press.

Labov, William. 1972a. Hypercorrection by the lower middle class as a factor in linguistic change. In Sociolinguistic patterns, 122-42. Philadelphia: University of Pennsylvania Press.

. 1972b. On the mechanism of linguistic change. In Sociolinguistic patterns, 160-82. Philadelphia: University of Pennsylvania Press.

- 1991. The three dialects of English. In New ways of analyzing sound change, ed. P. Eckert, 1-44. New York: Academic Press.

Labov, William, Sharon Ash, and Charles Boberg. 2005. Atlas of North American English. Berlin: Mouton de Gruyter.

Lubove, R. 1969. Twentieth century Pittsburgh. Vol. 1, Government, business and environmental change. New York: John Wiley.

McCool, Sam. 1982. Sam McCool's new Pittsburghese: How to speak like a Pittsburgher. Pittsburgh, PA: Hayford.

McDavid, Raven I., et al. 1980. Linguistic atlas of the Middle and South Atlantic states. 2 Fascicles. Chicago: University of Chicago Press.

McElhinny, Bonnie. 1999. More on the third dialect of English: Linguistic constraints on the use of three phonological variables in Pittsburgh. Language Variation and Change 11:171-95.

McGough, Michael. 1973. Pitsburghers have a dialect all their own. Pittsburgh Post-Gazette, October 15, p. 1. Milroy, Lesley. 1987. Language and social networks. 2nd ed. Oxford, UK: Basil Blackwell.

, ed. 2002. Investigating change and variation through dialect contact. Theme issue, Journal of Sociolinguistics 6 (1): 3-130. 
Milroy, James, and Lesley Milroy. 1985. Authority in language: Investigating language prescription and standardization. London: Routledge and Kegan Paul.

Modell, Judith. 1999. A town without steel: Envisioning Homestead. With photographs by Charlee Brodsky. Pittsburgh, PA: University of Pittsburgh Press.

Oestreicher, Richard. 1989. Working-class formation, development, and consciousness in Pittsburgh, 1790-1960. In City at the point: Essays on the social history of Pittsburgh, ed. S. P. Hayes, 111-50. Pittsburgh, PA: University of Pittsburgh Press.

Pitz, Marilynne. 2001. Patter, patois, or pidgin, it's the talk of the town. Pittsburgh Post-Gazette, February 11. Preston, Dennis R. 1989. Perceptual dialectology. Dordrecht, the Netherlands: Foris.

Preston, Dennis R., and Nancy Niedzielski. 1999. Folk linguistics. Amsterdam: John Benjamins.

Schilling-Estes, Natalie. 1998. Investigating "self-conscious" speech: The performance register in Ocracoke English. Language in Society 27:53-83.

Silverstein, Michael. 1976/1995. Shifters, linguistic categories, and cultural description. In Language, culture, and society: A book of readings, ed. B. G. Blount, 187-221. Prospect Heights, IL: Waveland. 1998. Contemporary transformations of local linguistic communities. Annual Review of Anthropology 27:401-26.

2003. Indexical order and the dialectics of sociolinguistic life. Language and Communication 23:193-229.

. 2004. "Cultural" concepts and the language-culture nexus. Current Anthropology 45:621-52.

Swetnam, George. 1959. Pittsburgh patois. Pittsburgh Press, September 6, p. 4.

Trudgill, Peter. 1972. Sex and covert prestige: Linguistic change in the urban dialect of Norwich. Language in Society 1:179-95.

1986. Dialects in contact. Oxford, UK: Basil Blackwell.

Wolfram, Walt. 2003. On the construction of vernacular dialect norms. In Sociolinguistics: The essential readings, ed. Christina Bratt Paulston and G. Richard Tucker, 251-71. Malden, MA: Blackwell.

Barbara Johnstone is a professor of rhetoric and linguistics at Carnegie Mellon University and editor of Language in Society. She is the author of Repetition in Arabic Discourse (Benjamins, 1990); Stories, Community, and Place: Narratives from Middle America (Indiana University Press, 1990); The Linguistic Individual (Oxford, 1996); and two textbooks, Qualitative Methods in Sociolinguistics (Oxford, 2001) and Discourse Analysis (Blackwell, 2002), in addition to many articles and book chapters. Her research interests have to do with how people evoke and shape places in talk and with what can be learned by taking perspective of the individual on language and discourse.

Jennifer Andrus is a graduate student in the Rhetoric Program at Carnegie Mellon University.

Andrew E. Danielson handles administrative systems projects at the University of California, Berkeley's, University Relations department. He obtained a bachelor's degree in comparative literature from the Pennsylvania State University (1993). A former staff member at Carnegie Mellon University at Pittsburgh, he studied with Professor Johnstone as a nondegree student. 